\title{
Moulting and growth of the early stages of two species of Antarctic calanoid copepod in relation to differences in food supply
}

\author{
Rachael S. Shreeve*, Peter Ward \\ British Antarctic Survey, Natural Environment Research Council, Madingley Road, Cambridge CB3 OET, United Kingdom
}

\begin{abstract}
Instantaneous measurements of moulting and growth of the early copepodite stages of 2 species of Antarctic copepod, Rhincalanus gigas and Calanoides acutus, were made at 4 regions around South Georgia during austral summer 1996/1997. Sea surface temperature was $-3^{\circ} \mathrm{C}$ across the study area whereas chlorophyll a concentrations were considerably higher towards the western end of the island. Despite this, moulting rate experiments showed that stage durations of both species were invariably short with no significant regional differences. Stage durations of $R$. gigas $\mathrm{CI}$, CIl and CIII averaged 9,28 and 15 d respectively, and those of CII, CIII and CIV C. acutus were 4, 7, and $16 \mathrm{~d}$ respectively. Daily mass-specific growth rates were lower and less variable in $R$. gigas (mean $0.05 \mathrm{~d}^{-1}$ ) than in $C$. acutus (mean $0.14 \mathrm{~d}^{-1}$ ), and showed no measurable regional differences. Those for $C$. acutus however, were higher off-shelf at the western end of the island where the copepodites were heavier than elsewhere. In addition to variations in concentration of chlorophyll $a$, qualitative differences in the microplankton food supply may also have influenced growth rates. Large diatoms were far more abundant off-shelf at the western end of the island compared to elsewhere, where micro-flagellates and small diatoms dominated. It is suggested that the more opportunistic feeding mode of $R$. gigas gave stability to its growth rate, whereas $C$. acutus, which is predominantly herbivorous, was affected by the fluctuations in phytoplankton concentrations and species composition. Moulting occurred within a narrow range of carbon and dry mass for both species, although this range varied between stations.
\end{abstract}

KEY WORDS: Rhincalanus gigas - Calanoides acutus - Moulting rates - Growth · Production - Southern Ocean. South Georgia

\section{INTRODUCTION}

Rhincalanus gigas and Calanoides acutus are large Southern Ocean copepods which are major contributors to zooplankton biomass (Voronina 1970, Hopkins 1971) and important intermediaries in the food web (Hopkins 1971). Several aspects of their life cycle are now fairly well known, for example seasonal vertical migration (Andrews 1966, Voronina et al. 1978), diapause and lipid storage (Marin 1988, Bathmann et al. 1993. Hagen \& Schnack-Schiel 1996) and seasonal changes in age structure (Schnack-Schiel \& Hagen 1994, Atkinson et al. 1997, Ward et al. 1997). Although

•E-mail: rssh@pcmail.nerc-bas.ac.uk we are close to constructing energy budgets for these 2 species, there is a crucial lack of information on their growth rates, particularly for the younger copepodite stages. Egg production rates have been measured for $R$. gigas and C. acutus in several locations (Huntley \& Lopez 1992, Lopez et al. 1993, Ward \& Shreeve 1995) but these do not necessarily equate to growth rates of early copepodite stages (Peterson et al. 1991). Exponential growth models have been applied (Conover \& Huntley 1991, Atkinson 1998) using development time from first feeding to diapausing late copepodites and estimated carbon masses (Conover \& Huntley 1991), but for polar copepods with lipid stores and arrested development, such models are at best approximations. Also the high advection rates typical of the Southern 


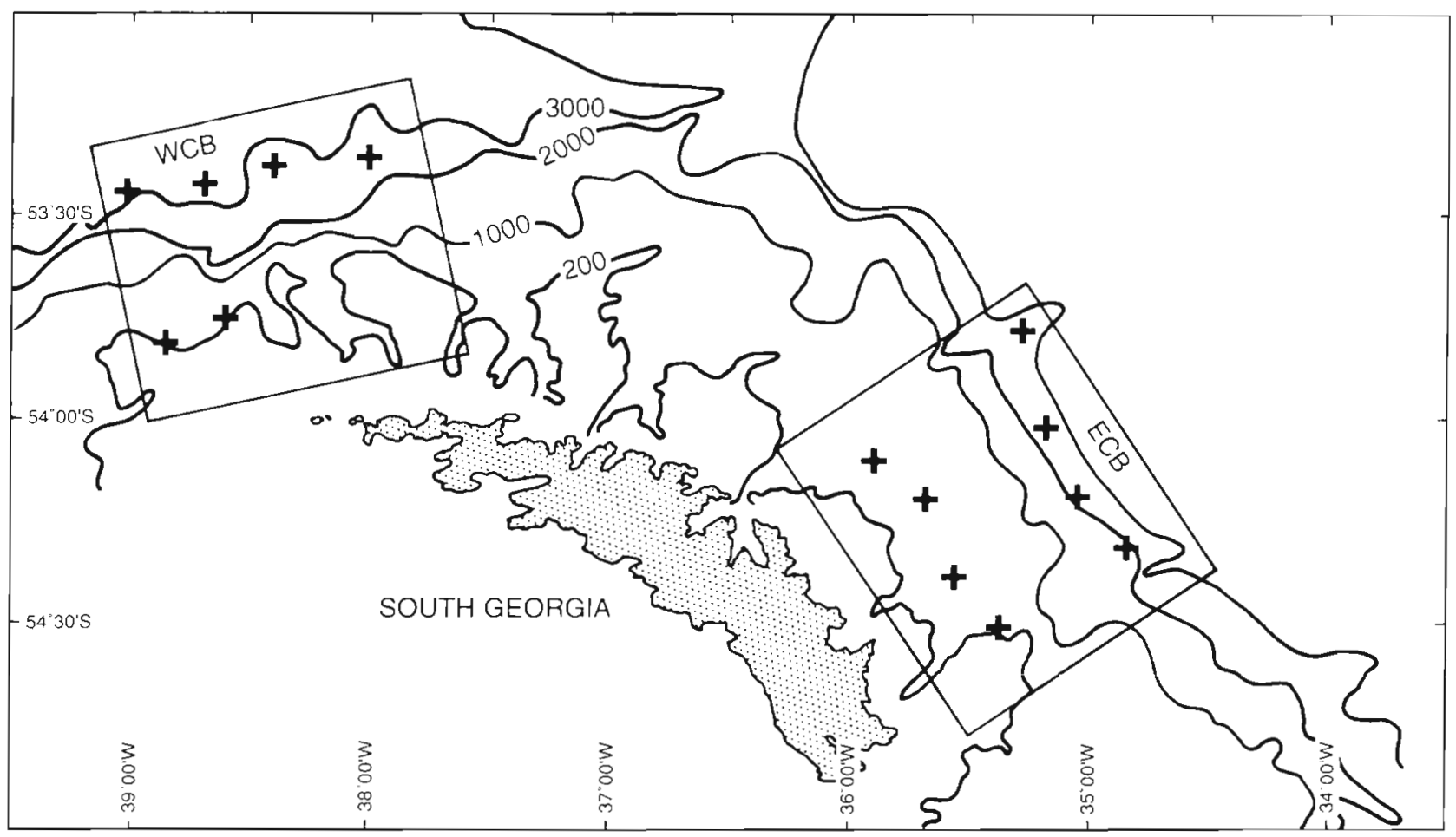

Fig. 1 Study site, showing South Georgia shaded in grey, 200, 1000, 2000 and $3000 \mathrm{~m}$ isobath.s and sampling stations. Outlined areas define the Western and Eastern Core Boxes (WCB and ECB respeclively)

Ocean mean that development rates cannot be estimated reliably from observed changes in age structure. An energy budget approach was used by Schnack et al. (1985) to determine growth rates, but this indirect approach suffers from the need for precise and simultaneous measurements of feeding, assimilation and respiration rates

A fourth approach to estimate growth rates is used in this study. This involves measuring the moulting rates of freshly caught copepodite stages and calculating their growth rates from a mean mass for that stage (Runge et al. 1985). This was done as part of a programme to investigate variability within the productive South Georgia region, an important copepod/krill dominated ecosystem supporting commercially exploited stocks (Everson 1977). Primary production north of the island is high compared to elsewhere in the Southern Ocean (Hart 1942) but blooms are by no means seasonally dependent. Calanoides acutus and Rhincalanus gigas have been the focus of intense study here, in order to examine how they respond to variability in primary production and translate it into secondary production (Ward \& Shreeve 1995, Atkinson et al. 1996, Pakhamov et al. 1997).

This study is the first to estimate growth rates of Antarctic copepods directly, using the moulting rate method. Early copepodite stages of Rhincalanus gigas and Calanoides acutus were monitored, because their appearance coincides with phytoplankton blooms and successful exploitation of food and rapid growth may be crucial to maintain their populations. The aim of this study was to see how moulting and growth rates were affected by variations in the composition and size of the microplankton over the study area.

\section{MATERIALS AND METHODS}

Study location and sample collection. During December 1996/January 1997 plankton samples were taken as part of a multi-disciplinary study of physical and biological variability of the South Georgia ecosystem. Two main areas were investigated, one to the northwest and the other to the northeast of the island These will be referred to as the Western Core Box (WCB) and Eastern Core Box (ECB) respectively (Fig. 1). Ten $80 \mathrm{~km}$ transects were run perpendicular to the shelf break within each of the core boxes. Continuous measurements were made of seawater temperature, salinity and chlorophyll a, from a pumped supply located at $7 \mathrm{~m}$ depth in the ship's hull. Six stations were sampled in the WCB and 8 in the ECB, 
representing on- and off-shelf locations (Fig. 1). In this study the term on-shelf refers to water depths $<400 \mathrm{~m}$, and off-shelf $>400 \mathrm{~m}$. Plankton samples were taken at these stations with a bongo net fitted with a motion compensating spring to minimise abrasion to the catch. The bongo frame was equipped with a $200 \mu \mathrm{m}$ mesh net of $61 \mathrm{~cm}$ mouth opening and a $5 \mathrm{l}$ non-filtering cod end. The net was hauled vertically from $200 \mathrm{~m}$ to the surface at 10 to $13 \mathrm{~m} \mathrm{~min}^{-1}$. Once on board samples were diluted in approximately $20 \mathrm{l}$ of ambient surface seawater. Samples were then sorted for experimental work and the residue preserved in $4 \%$ formaldehyde in seawater. Sorting took place within $3 \mathrm{~h}$ post capture during which time the temperature of the seawater which the copepods were in was maintained as close as possible $\left( \pm 1^{\circ} \mathrm{C}\right)$ to the ambient sea surface temperature. Water samples taken at each station for chlorophyll a and nutrient analyses were collected using a General Oceanics water-bottle rosette system mounted on a Neil Brown Mark 3 CTD. Subsamples of water representative of the mixed layer were preserved in $1 \%$ acid Lugol's solution.

Water used to incubate the copepods in during the moulting rate experiments was collected from a pumped non toxic seawater supply from an inlet at $7 \mathrm{~m}$ depth in the ship's hull. Filtration took place by pumping water through a series of $3 \mathrm{Balston}^{\mathrm{B}}$ filters of pore size 25, 1 and $0.2 \mu \mathrm{m}$, to remove predators and bacteria. Experiments subsequent to filtration indicated a dissolved oxygen concentration in the water of $92 \%$ saturation.

Moulting rate experiments. These were set up according to the method of Runge et al. (1985). Individual copepodite stages of Rhincalanus gigas and Calanoides acutus were removed under the dissection microscope using a wide bore pipette. Groups of 30 individuals of the same species and stage were placed in 2.51 jars of $0.2 \mu \mathrm{m}$ filtered seawater and incubated for $48 \mathrm{~h}$ under constant low illumination at ambient sea surface temperature. At the end of the incubation period the samples were filtered down and individual stages counted. Moulting rates were calculated using the equation

$$
M R_{1}=\frac{N_{f,(i+1)}}{N_{\mathrm{s}, 1}}
$$

where $M R_{i}$ is the moulting rate of stage $i, N_{\mathrm{s}, l}$ is the number of copepodites at stage $i$ at the start of the incubation, and $N_{t, i+1)}$ is the number of animals which had moulted to stage $i+1$ by the end of the incubation. To calculate the moulting rate $\mathrm{d}^{-1}, M R_{i}$ was then divided by the length of the incubation in days. Stage durations (in days) were calculated as the reciprocal of the moulting rates. Confidence intervals $(95 \%)$ for the sample fraction were constructed from statistical tables (Neave 1981) and these were transformed to reciprocals to express them as a function of time.

Egg production experiments. Adult females of Rhincalanus gigas and Calanoides acutus were taken at the same stations as juveniles for moulting rate experiments. Three groups of 10 females of each species were transferred into perspex cylinders $(750 \mathrm{ml})$ closed off at the lower end with $800 \mu \mathrm{m}$ mesh. These were then suspended in $1.5 \mathrm{l}$ glass jars of filtered seawater and incubated for $24 \mathrm{~h}$ at ambient sea surface temperature $\left(\sim 3^{\circ} \mathrm{C}\right)$. At the end of the incubation period eggs were removed and counted.

Dry mass and carbon analyses. Copepods were placed in pre-weighed tin foil capsules, dried on board ship at $60^{\circ} \mathrm{C}$ and transferred to the UK in a desiccator for dry mass and carbon analysis. Younger copepodite stages were pooled in groups of $\sim 30$ to provide enough material to work on. In the $\mathrm{UK}_{1}$ samples were again dried at $60^{\circ} \mathrm{C}$ to ensure a constant weight, and their dry mass measured on a Mettler MT5 balance to an accuracy of $\pm 1 \mu \mathrm{g}$. Whole samples of 1 to $5 \mathrm{mg}$ were then analysed for carbon, hydrogen and nitrogen, using a Fisons EA 1108 elemental analyser. Acetanilide was used as the standard because it has a carbon to nitrogen ratio (i.e. $7: 1$ ) similar to that anticipated in the zooplankton samples.

Zooplankton analyses. Formaldehyde preserved samples from the $200 \mu \mathrm{m}$ mesh net were analysed using a Wild M5 dissection microscope. All copepod taxa were enumerated and copepodite stage frequency determined for the dominant copepods. Where necessary, subsampling took place using a Folsom splitter. Abundances were expressed as number of individuals $\mathrm{m}^{-2}$ within the top $200 \mathrm{~m}$ of the water column. Copepod biomass estimates were made using carbon mass determined directly for the 2 species in this study and previously derived values from the same area for the remainder.

Food environment. Chlorophyll a concentrations measured at standard depths of $6,20,40,60,80,100$ and $125 \mathrm{~m}$ were integrated over this depth range and estimates of the algal carbon biomass made using a carbon:chloropyll a ratio of 50 . Subsamples of water representative of the mixed layer, generally from the chlorophyll maximum, were preserved in $1 \%$ acid Lugol's solution from each cast. A. $50 \mathrm{ml}$ aliquot of each sample was settled for $24 \mathrm{~h}$ using the Utermöhl technique and enumerated under an inverted microscope. The emphasis on identification was to group diatoms, micro-flagellates, dinoflagellates and ciliates according to size. A maximum dimension of $5 \mu \mathrm{m}$ was used as a size cut-off as this is roughly the lower size limit for efficient particle capture by copepods (Nival \& Nival 1976). 


\section{RESULTS}

\section{Environment}

In the ECB a pronounced shelf break front retained the identity of the water mass and associated plankton over the shelf in contrast to in the WCB, where there was more evidence of mixing between the on-shelf and off-shelf sites. Surface seawater temperature was $\sim 3^{\circ} \mathrm{C}$ at all stations and the bottom of the mixed layer was between 60 and $100 \mathrm{~m}$.

Chlorophyll a concentrations differed considerably among sites. Estimates of algal carbon biomass are summarised in Table 1 . Highest values were found offshelf in the WCB, where the mean carbon concentration was nearly double that of the on-shelf site, $16.75 \pm$ 3.25 compared to $9.63 \pm 5.25 \mathrm{~g} \mathrm{C} \mathrm{m}^{-2}$. In the ECB concentrations were lower with slightly higher levels onshelf, $6.13 \pm 1.5$ compared to $3.88 \pm 0.56 \mathrm{~g} \mathrm{C} \mathrm{m}^{-2}$. Measurements of nitrate, nitrite and ammonium showed low depletion of nutrients in the ECB compared with the WCB, indicating that the phytoplankton bloom was more advanced in the latter box. Counts of the main microplankton taxa, summarised in Table 1, show differences in the numbers in each size class among sites. In the WCB, off-shelf, large diatoms $1>10 \mu \mathrm{m}$ wide $x$ $50 \mu \mathrm{m}$ long) were much more abundant than in the 3 other areas, with mean concentrations in excess of 1500 cells $~^{-1}$ compared to a maximum of 110 cells $t^{-1}$ in the other 3 areas. In contrast, the on-shelf area of the WCB was dominated by micro-flagellates $(<5 \mu \mathrm{m})$ with counts in excess of 1000 cells $l^{-1}$ far outnumbering concentrations of other potential food taxa in this area. In the ECB there was less contrast in numbers of the various groups on- and off-shelf; however, when larger sized taxa were compared to the WCB, ciliates were more numerous in the $\mathrm{ECB}$, a mean value for the $\mathrm{ECB}$ of 299 cells $\mathrm{ml}^{-1}$ compared to only 11 cells $\mathrm{ml}^{-1}$ in the WCB

\section{Stage frequency, egg production and zooplankton biomass}

The stage frequency of Rhincalanus gigas in the top $200 \mathrm{~m}$ varied between the core boxes (Fig. 2a) but the presence of younger copepodite stages indicated that recruitment was occurring at all stations. On-shelf in the WCB the population of $R$. gigas was made up mainly of older stages, including adult males, while younger copepodites (stages CI to CIII) made up $<10 \%$ of the population. This was in marked contrast to offshelf at the WCB and both on-and off-shelf at the ECB, where 50,30 and $>50 \%$ of the population respectively comprised younger copepodite stages, and males made up a much lower proportion of the population. Low egg production rates ( 0 to 0.7 eggs female ${ }^{-1} \mathrm{~d}^{-1}$ ) were observed in the ECB both on- and off-shelf, whilst rates reached 7.2 and 10 eggs female ${ }^{-1} \mathrm{~d}^{-1}$ offand on-shelf respectively in the WCB. Total abundances of $R$. gigas were similar between on- and offshelf in the ECB at 4000 ind. $\mathrm{m}^{-2}$. In the WCB, abundances were much more variable, from 2000 ind. $\mathrm{m}^{-2}$ on-shelf to 22000 ind. $\mathrm{m}^{-2}$ off-shelf.

Calanoides acutus showed a different age structure to Rhincalanus gigas (Fig. 2b). Off-shelf in both core boxes there was a higher proportion of younger stages (CI to CIV) than on-shelf. While the absence of females off-shelf in the ECB suggested that reproduction was over in this area, it was still in progress in the WCB (average 13 eggs female ${ }^{-1} \mathrm{~d}^{-1}$ ). On-shelf the proportion of younger copepodite stages was small, and females

Table 1. Copepod and algal carbon biomass estimates. Copepod biomass ( \pm SD) is based on data collected from the top $200 \mathrm{~m}$ of the water column, using direct measures of carbon made in this study or assuming carbon is $45 \%$ of dry mass (Schnack et al. 1985). Algal carbon biomass ( \pm SD) was determined from mean chl a values integrated over the top $125 \mathrm{~m}$ of the water column using a carbon:chl a ratio of 50 . Mean number of microplankton taxa (numbers $10 \mathrm{ml}^{-1} \pm \mathrm{SD}$ ) counted from Lugol's samples are listed, showing size categories in parentheses giving approximate diameters (diam.) of near circular food items and length and width of diatoms. "Dominant copepod species: Rhincalanus gigas, Calanoides arutus, Calanus simillimus, Calanus propinquus, Oithona sp.. Ctenocalanus sp., Metridia sp. Pleuromamma sp. "Main species making up large diatom taxa: Eucampia antarctica, Corethron criophilum. Thalassiosira sp., Nitzschia sp., Thalassionema sp. 'Main species: Chaetoceros sp.

\begin{tabular}{|c|c|c|c|c|}
\hline & \multicolumn{2}{|c|}{ Western Core Box (WCB) } & \multicolumn{2}{|c|}{ Eastern Core Box (ECB) } \\
\hline & Off-shelf & On-shelf & Off-shelf & On-shelf \\
\hline Copepod biomass $\left(\mathrm{g} \mathrm{C}^{-2}\right)$ & $5.31 \pm 0.67$ & $0.64 \pm 0.42$ & $1.01 \pm 0.46$ & $0.80 \pm 0.27$ \\
\hline Algal carbon biomass $\left(\mathrm{g} \mathrm{C} \mathrm{m}^{-2}\right)$ & $16.75 \pm 3.25$ & $9.63 \pm 5.25$ & $3.88 \pm 0.56$ & $6.13 \pm 1.5$ \\
\hline Large diatoms $(>10 \times 50 \mu \mathrm{m})$ & $1671 \pm 755$ & $25 \pm 35$ & $48 \pm 47$ & $110 \pm 93$ \\
\hline Large dinoflagellates (> $1.0 \mu \mathrm{m}$ d.am.) & $128 \pm 22$ & $25 \pm 22$ & $51 \pm 2.08$ & $68+39$ \\
\hline Ciliates $(10$ to $30 \mu \mathrm{m}$ diam. $)$ & $15 \pm 22$ & $6 \pm 8.32$ & $278 \pm 380$ & $319 \pm 525$ \\
\hline Small cubic diatoms $(<5 \times 5 \mu \mathrm{m})$ & $2557 \pm 1264$ & $4 \pm 6.24$ & $227 \pm 313$ & $199 \pm 170$ \\
\hline Micro-flagellates $(<5$ um diam.) & $499 \pm 45$ & $1079 \pm 1513$ & $467 \pm 141$ & $756 \pm 178$ \\
\hline
\end{tabular}



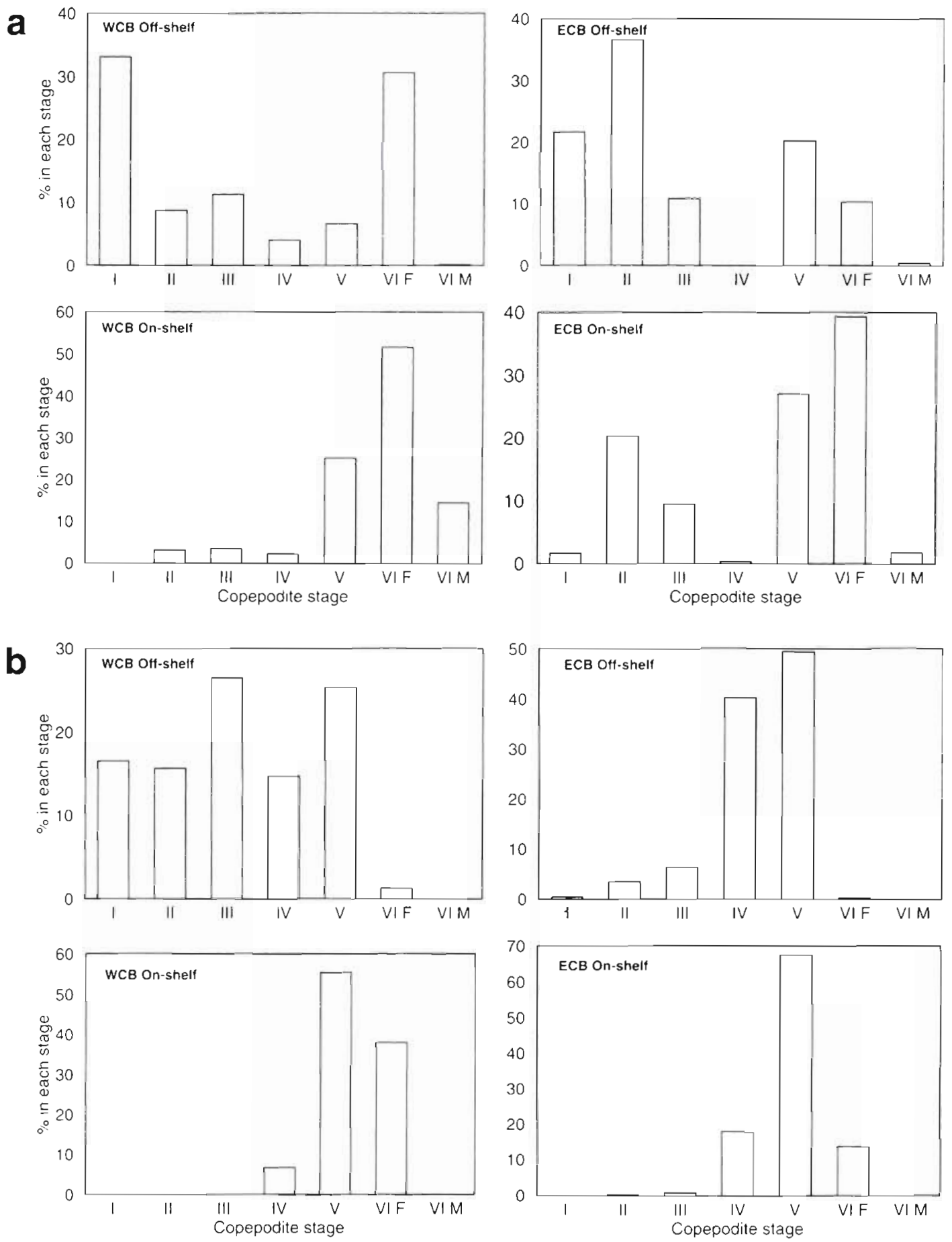

Fig. 2. (a) Rhincalanus gigas and (b) Calanoides acutus. Mean copepodite stage frequencies in the Western and Eastern Core Boxes (WCB and ECB respectively), on-shelf and off-shelf locations

were producing eggs at the rate of 23 and 3.1 female $^{-1}$ $\mathrm{d}^{-1}$ in the WCB and ECB respectively. Total abundance of $C$. acutus copepodites was variable, with higher values off-shelf at both sites. In the ECB, abundances ranged from 4000 ind. $\mathrm{m}^{-2}$ on-shelf to 12000 ind. $\mathrm{m}^{-2}$ off-shelf and from 2000 ind. $\mathrm{m}^{-2}$ on-shelf to 47000 ind. $\mathrm{m}^{-2}$ off-shelf at the WCB.

Biomass estimates of the dominant copepod taxa ( $\mathrm{g} \mathrm{C} \mathrm{m}^{-2}$ ) based on numbers of copepods counted from vertical hauls of the top $200 \mathrm{~m}$ of the water column are 
Table 2. Rhincalanus gigas and Calanoides acutus. Copepodite stage durations (d) estimated from the moulting rate experiments at the Western and Eastern Core Boxes (WCB and ECB respectively), off-shelf and on-shelf. Stage duration is followed in parentheses by the number of individuals used for the determination. Confidence intervals (95\%) were transformed to reciprocals to represent the range of stage durations. NM: stages where individuals were not moulting during the course of the experiments. -: no data collected

\begin{tabular}{|c|c|c|c|c|c|c|c|c|}
\hline \multirow[t]{2}{*}{ Copepodite stage } & \multicolumn{2}{|c|}{ WCB off-shelf } & \multicolumn{2}{|c|}{ WCB on-shelf } & \multicolumn{2}{|c|}{ ECB off-shelf } & \multicolumn{2}{|c|}{ ECB on-shelf } \\
\hline & $\begin{array}{c}\text { Stage } \\
\text { duration }\end{array}$ & $95 \% \mathrm{CI}$ & $\begin{array}{c}\text { Stage } \\
\text { duration }\end{array}$ & $95 \% \mathrm{CI}$ & $\begin{array}{c}\text { Stage } \\
\text { duration }\end{array}$ & $95 \% \mathrm{CI}$ & $\begin{array}{c}\text { Stage } \\
\text { duration }\end{array}$ & $95 \% \mathrm{CI}$ \\
\hline \multicolumn{9}{|l|}{ Rhincalanus gigas } \\
\hline $\mathrm{CI}$ & $10(485)$ & $7-13$ & - & - & $8(105)$ & $5-14$ & - & - \\
\hline CII & $37(448)$ & $19-50$ & - & - & $31(280)$ & $17-56$ & $15(123)$ & $7-33$ \\
\hline CIII & $15(214)$ & $7-25$ & - & - & $N M(65)$ & - & $\mathrm{NM}(41)$ & - \\
\hline CIV & NM $(78)$ & - & - & - & - & - & $N M(31)$ & - \\
\hline$C V$ & NM (15) & - & $N M(45)$ & - & - & - & - & - \\
\hline \multicolumn{9}{|l|}{ Calanoides acutus } \\
\hline CII & $4(104)$ & $3-6$ & - & - & - & - & - & - \\
\hline CIII & $8(423)$ & $6-11$ & - & - & $10(58)$ & $3-11$ & - & - \\
\hline CIV & $11(225)$ & $8-15$ & - & - & $22(351)$ & $13-33$ & $16(190)$ & $8-33$ \\
\hline $\mathrm{CV}$ & $N M(176)$ & - & NM (110) & - & NM (336) & - & NM (188) & - \\
\hline
\end{tabular}

summarised in Table 1 Biomass was over 5 times as great off-shelf in the WCB $\left(5.31 \pm 0.67 \mathrm{~g} \mathrm{C} \mathrm{m}^{-2}\right)$ compared to in the ECB $\left(1.01 \pm 0.46 \mathrm{~g} \mathrm{C} \mathrm{m}^{-2}\right)$; on-shelf in both boxes biomass was relatively low at 0.64 to $0.80 \mathrm{~g}$ $\mathrm{C} \mathrm{m}^{-2}$.

\section{Stage duration}

Stage durations and confidence intervals (95\%), which were transformed to reciprocals to represent the range of stage durations, are summarized in Table 2. Stage duration was generally short in the younger copepodite stages of both species, with Rhincalanus gigas generally having slightly longer durations than similar stages of Calanoides acutus. In all cases confidence intervals of specific species stages overlapped, showing that stage durations with respect to region, although variable, did not differ significantly, and that environmental differences among the 4 regions were not detectably affecting development rates. Moulting did not occur in $R$. gigas stage CIII in the ECB either on or off-shelf, or in stage $\mathrm{CV}$ of either species during these experiments. Moulting rates of stage CII $R$. gigas were slower than we would have anticipated from the rates of CI. We know of no ontogenetic reason why stage durations of CIIs should be protracted (see Hart 1990) and plausible environmental explanations for this phenomenon are not obvious.

\section{Dry mass and carbon}

Dry mass and carbon values for Rhincalanus gigas and Calanoides acutus with respect to site were derived from copepodites used in both the moulting and the egg production experiments and a distinction was made between individuals that had and had not moulted in the incubations prior to their preservation (Table 3). The former measurement will give a mean mass biased towards individuals which have just entered that stage and the latter will represent individuals at a greater range of age within stage. Both species differed clearly among regions, with dry and carbon mass for the non-moulting representatives of both species being higher in the off-shelf portion of the WCB than at any of the other regions. Thus, for example, $R$. gigas CVs and females were approximately twice as heavy and $C$. acutus CVs up to 3 times as heavy as elsewhere. These differences were probably due to increases in stored lipid in this region. The carbon to nitrogen mass ratio in copepods reflects their protein to lipid ratio. Younger stages and older stages that have very little lipid reserves have a low $\mathrm{C}: \mathrm{N}$ ratio, which reflects their predominantly protein composition, whereas older stages, with larger lipid reserves, have higher $C: N$ ratios. This increase in the $C: N$ with progressively older stages is shown in Table 4. In female $R$. gigas, C:N ranged from 4.59 on-shelf in the WCB up to 8.03 off-shelf in the WCB. Similarly, C. acutus females ranged from 6.61 on-shelf at the ECB to 8.59 off-shelf at the WCB. In younger copepodite stages ( $\mathrm{CI}$ to $\mathrm{CIII}$ ) the ratio of $\mathrm{C}: \mathrm{N}$ was about 3 at all sites. Differences in dry and carbon mass for newly moulted copepodites were not as marked among sites as for non-moulters but when they occurred they generally reflected the same pattern, i.e. those derived from the off-shelf part of the WCB were heavier than elsewhere. They were also considerably more restricted in range, and to illustrate this $\log _{10}$ dry mass 
Table 3. Rhincalanus gigas and Calanoides acutus. Mean and standard error of dry mass (DM, $\mu \mathrm{g}$ ) and carbon mass (CM, $\mu \mathrm{g}$ ) measured at the Western and Eastern Core Boxes (WCB and ECB respectively), off-shelf and on-shelf. E: individuals which were kept in experimental conditions and did not moult; $M$ : those which moulted into specified stage during the experiment. Copepodite stages CI to CV were held for $48 \mathrm{~h}$ in moulting rate experiments and females were held for $24 \mathrm{~h}$ in egg production experiments. N: total number of individuals used for a determination, followed in parentheses by the number of replicates. -: values not determined

\begin{tabular}{|c|c|c|c|c|c|c|c|c|c|c|c|c|}
\hline \multirow{2}{*}{$\begin{array}{l}\text { Stage/ } \\
\text { origin }\end{array}$} & \multicolumn{3}{|c|}{ WCB off-shelf } & \multicolumn{3}{|c|}{ WCB on-shelf } & \multicolumn{3}{|c|}{$E C B$ off-shelf } & \multicolumn{3}{|c|}{ ECB on-shelf } \\
\hline & N & $\begin{array}{c}\text { Mean } \\
\mathrm{DM} \pm \mathrm{SE}\end{array}$ & $\begin{array}{c}\text { Mean } \\
\mathrm{CM} \pm \mathrm{SE}\end{array}$ & N & $\begin{array}{c}\text { Mean } \\
\mathrm{DM} \pm \mathrm{SE}\end{array}$ & $\begin{array}{c}\text { Mean } \\
\mathrm{CM} \pm \mathrm{SE}\end{array}$ & N & $\begin{array}{c}\text { Mean } \\
\mathrm{DM} \pm \mathrm{SE}\end{array}$ & $\begin{array}{c}\text { Mean } \\
\mathrm{CM} \pm \mathrm{SE}\end{array}$ & $N$ & $\begin{array}{c}\text { Mean } \\
\mathrm{DM} \pm \mathrm{SE}\end{array}$ & $\begin{array}{c}\text { Mean } \\
\mathrm{CM} \pm \mathrm{SE}\end{array}$ \\
\hline \multicolumn{13}{|c|}{ Rhincalanus gigas } \\
\hline $\mathrm{CI} / \mathrm{E}$ & $390(21)$ & $40 \pm 6$ & $7 \pm 1$ & - & - & - & $68(4)$ & $37 \pm 9$ & $5 \pm 0.9$ & - & - & - \\
\hline $\mathrm{ClI} / \mathrm{M}$ & $93(11)$ & $60 \pm 10$ & $10 \pm 1.3$ & - & - & - & $25(8)$ & $56 \pm 6$ & $7 \pm 1.0$ & - & - & - \\
\hline $\mathrm{CII} / \mathrm{E}$ & $424(36)$ & $72 \pm 10$ & $15 \pm 3$ & - & - & - & $249(21)$ & $62 \pm 11$ & $9 \pm 1.7$ & $117(14)$ & $75 \pm 11$ & $12 \pm 2.6$ \\
\hline CIII/M & $23(9)$ & $119 \pm 10$ & $26 \pm 3$ & - & - & - & $17(3)$ & $93 \pm 18$ & $17 \pm 5$ & $17(4)$ & $103 \pm 23$ & $17 \pm 4.8$ \\
\hline ClII/E & $159(46)$ & $169 \pm 40$ & $46 \pm 24$ & - & - & - & $61(8)$ & $109 \pm 9$ & $16 \pm 4.1$ & $45(36)$ & $152 \pm 41$ & $26 \pm 13.8$ \\
\hline $\mathrm{CIV} / \mathrm{M}$ & $25(9)$ & $318 \pm 21$ & $90 \pm 9.5$ & - & - & - & - & - & - & - & - & - \\
\hline CIV/E & $78(42)$ & $402 \pm 79$ & $134 \pm 27$ & $9(9)$ & $316 \pm 80$ & $83 \pm 41$ & - & - & - & - & - & - \\
\hline CV/E & $15(15)$ & $\begin{array}{r}2158 \\
\pm 719\end{array}$ & $\begin{array}{r}1506 \\
+321\end{array}$ & $45(21)$ & $\begin{array}{c}917 \\
\pm 248\end{array}$ & $\begin{array}{c}342 \\
\pm 168\end{array}$ & - & - & - & $42(42)$ & $\begin{array}{r}1170 \\
+544\end{array}$ & $\begin{array}{c}763 \\
\pm 370\end{array}$ \\
\hline CVI F/E & $113(113)$ & $\begin{array}{r}2976 \\
\pm 829\end{array}$ & $\begin{array}{r}1604 \\
\pm 512\end{array}$ & $57(57)$ & $\begin{array}{l}1504 \\
\pm 342\end{array}$ & $\begin{array}{c}645 \\
\pm 263\end{array}$ & $62(62)$ & $\begin{array}{l}1544 \\
\pm 326\end{array}$ & $\begin{array}{c}699 \\
\pm 199\end{array}$ & $117(117)$ & $\begin{array}{r}1856 \\
\pm 538\end{array}$ & $\begin{array}{c}858 \\
\pm 374\end{array}$ \\
\hline \multicolumn{13}{|c|}{ Calanoides acutus } \\
\hline ClI/E & $57\{2\}$ & $32 \pm 0.7$ & $\begin{array}{ll}7 & 4 \pm 0.01\end{array}$ & - & - & - & - & - & $=$ & - & - & - \\
\hline $\mathrm{CIII} / \mathrm{M}$ & $54(3)$ & $47 \pm 2$ & $6 \pm 0.23$ & - & - & - & - & - & - & - & - & - \\
\hline CIII/E & $272(36)$ & $64 \pm 6$ & $15 \pm 2.51$ & - & - & - & $33(4)$ & $43 \pm 6$ & $8 \pm 1.3$ & - & - & - \\
\hline $\mathrm{CIV} / \mathrm{M}$ & $107(19)$ & $97 \pm 16$ & $25 \pm 3.50$ & - & - & - & $25(3)$ & $64 \pm 9$ & $13 \pm 2.7$ & - & - & - \\
\hline CIV/E & $168(22)$ & $158 \pm 23$ & $56 \pm 14.9$ & - & - & - & $118(15)$ & $112 \pm 9$ & $25 \pm 5.8$ & $238(63)$ & $141 \pm 47$ & $57 \pm 11$ \\
\hline $\mathrm{CV} / \mathrm{M}$ & $32\{4\}$ & $258 \pm 6$ & $86 \pm 71$ & - & - & - & $42(9)$ & $199 \pm 52$ & $49 \pm 12.1$ & $28(1)$ & $203 \pm 55$ & $52 \pm 11$ \\
\hline$C V / E$ & $182(31)$ & $\begin{array}{c}676 \\
\pm 133\end{array}$ & $393 \pm 68$ & $110(20)$ & $497 \pm 87$ & $264 \pm 67$ & $307(56)$ & $243 \pm 46$ & $\begin{array}{c}109 \\
\pm 28.8\end{array}$ & $203(33)$ & $329 \pm 97$ & $114 \pm 70$ \\
\hline CVI F/E & $32(8)$ & $\begin{array}{c}886 \\
\pm 162\end{array}$ & $567 \pm 71$ & $68(7)$ & $580 \pm 75$ & $375 \pm 43$ & - & - & - & $116(13)$ & $713 \pm 74$ & $\begin{array}{c}371 \\
\pm 123\end{array}$ \\
\hline
\end{tabular}

Table 4. Rhincalanus gigas and Calanoides acutus. Specific growth rate $(g)\left(\mathrm{C} \mathrm{d}^{-1}\right)$ for the range of stages at each location measured. Estimates of $g$ were based on durations derived for that stage during the moulting rate experiments and carbon mass, both in terms of the mean value for newly moulted individuals $(M)$ and the mean value for individuals of the same stage but which did not moult during the experiments (E). Numbers in parentheses are the range of growth rates derived from ingestion rates, see text for details, Values given for each stage relate to that stage moulting into the next stage. NE: values not estimated because of a lack of 1 parameter. $\mathrm{C}: \mathrm{N}$ : carbon to nitrogen mass ratio

\begin{tabular}{|c|c|c|c|c|c|c|c|c|}
\hline \multirow{2}{*}{$\begin{array}{l}\text { Stage/ } \\
\text { origin }\end{array}$} & \multicolumn{2}{|c|}{ WCB off-shelf } & \multicolumn{2}{|c|}{ WCB on-shelf } & \multicolumn{2}{|c|}{ ECB off-shelf } & \multicolumn{2}{|c|}{ ECB on-shelf } \\
\hline & $g$ & $\mathrm{C}: \mathrm{N}$ & $g$ & $\mathrm{C}: \mathrm{N}$ & $g$ & $\mathrm{C}: \mathrm{N}$ & $g$ & $C: N$ \\
\hline \multicolumn{9}{|c|}{ Rhincalanus gigas } \\
\hline $\mathrm{CI} / \mathrm{E}$ & $0.08(0.02-0.18)$ & 3.13 & - & - & $0.07(0.03-0.10)$ & 2.70 & - & - \\
\hline $\mathrm{CII} / \mathrm{M}$ & $0.02(0.02-0.15)$ & 3.06 & - & - & $0.02(0.02-0.18)$ & 2.72 & - & - \\
\hline CIIFE & $0.03(0.02-0.13)$ & 3.05 & - & - & $0.02(0.02-0.17)$ & 2.57 & $0.04(0.02-0.14)$ & 2.62 \\
\hline $\mathrm{CIII} / \mathrm{M}$ & $0.07(0.01-0.10)$ & 3.41 & - & - & NE & 2.86 & NE & 2.72 \\
\hline CIYI/E & $0.07(0.01-0.09)$ & 4.33 & - & - & $\mathrm{NE}$ & 2.69 & $\mathrm{NE}$ & 2.89 \\
\hline $\mathrm{CIV} / \mathrm{M}$ & NE & 4.47 & - & - & - & - & - & - \\
\hline $\mathrm{CIV} / \mathrm{E}$ & NE & 4.80 & - & - & - & - & - & - \\
\hline $\mathrm{CV} / \mathrm{E}$ & $\mathrm{NE}$ & 8.41 & $\mathrm{NE}$ & 3.87 & - & - & NE & 5.10 \\
\hline CVI F/E & $\mathrm{NE}$ & 8.03 & $\mathrm{NE}$ & 4.59 & NE & 4.92 & $N E$ & 5.57 \\
\hline \multicolumn{9}{|c|}{ Calanoides acutus } \\
\hline CII/E & $0.33(0.09-0.42)$ & 3.23 & - & - & - & - & - & - \\
\hline $\mathrm{CIII} / \mathrm{M}$ & $0.18(0.08-0.35)$ & 3.14 & - & - & - & - & - & - \\
\hline $\mathrm{ClII} / \mathrm{E}$ & $0.16(0.05-0.25\}$ & 4.70 & - & - & $0.11(0.07-0.32)$ & 3.17 & - & - \\
\hline $\mathrm{CIV} / \mathrm{M}$ & $0.10(0.04-0.20)$ & 3.95 & - & - & $0.06(0.06-0.26)$ & 3.46 & - & - \\
\hline $\mathrm{CIV} / \mathrm{E}$ & $0.18(0.03-0.18)$ & 5.06 & - & - & $0.07(0.04-0.20)$ & 3.04 & $0.04(0.03-0.15)$ & 3.55 \\
\hline CV/M & $N E$ & 6.32 & - & - & $\mathrm{NE}$ & 3.52 & NE & 4.49 \\
\hline $\mathrm{CV} / \mathrm{E}$ & NE & 9.25 & $\mathrm{NE}$ & 7.69 & $\mathrm{NE}$ & 4.18 & NE & 5.27 \\
\hline CVI F/E & $\mathrm{NE}$ & 8.59 & NE & 8.01 & - & - & $N E$ & 6.61 \\
\hline
\end{tabular}



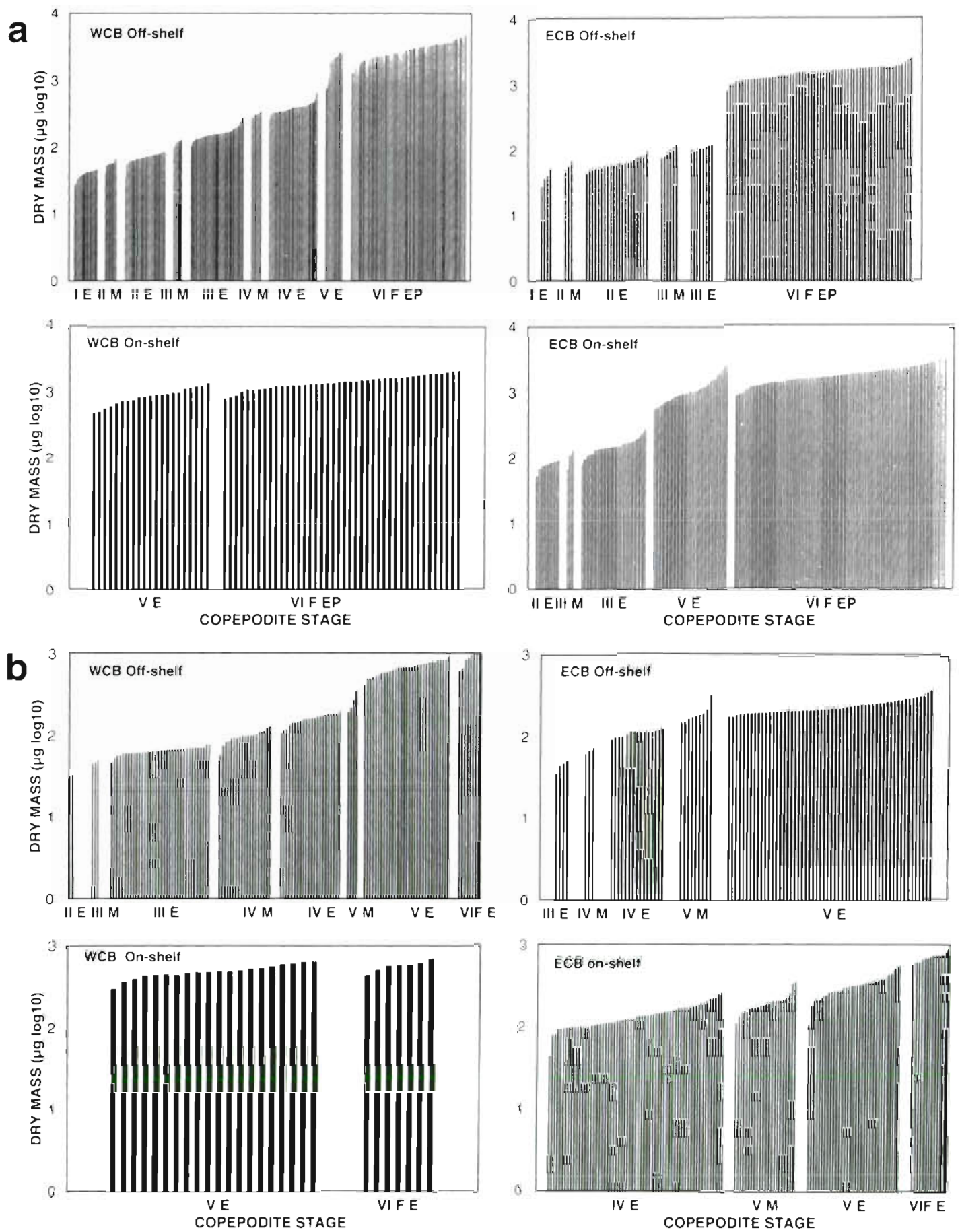

Fig. 3. (a) Rhincalanus gigas and (b) Calanoides acutus. $\log _{10}$ ranked dry mass ( $\mu$ g) of each group of individuals in each copepodite stage (I-VIF) at the WCB and ECB on- and off-shelf. E: individuals which were kept in experimental conditions and did not moult; $M$ : those which moulted into that stage during the experiment; EP: females held in egg production experiments. Each bar represents a measurement of dry mass; younger stages are represented by the mean value for each replicate (see Table 3 for the number of replicates and total number of individuals used in the analyses). Measurements for successive stages are defined by larger spaces

( $\mu$ g) has been ranked for each stage according to whether the animals moulted or not (Fig. $3 a, b)$. Although these data represent means of groups of indi- viduals, they nonetheless show that moulters generally fell between the heaviest individuals of the previous stage and the lightest of the current one. 


\section{Growth coefficients}

Instantaneous growth rates ( $\mathrm{gd}^{-1}$; Table 4$)$, were calculated from the measured carbon masses and stage durations for moulting juvenile stages, using the equation:

$$
g=\left(\ln W_{1+1}-\ln W_{i}\right) / t
$$

where $W_{i}$ is the mass on entry into stage $i(\mathrm{~g} \mathrm{C}), W_{i+1}$ the mass on entry into the subsequent stage ( $\mathrm{g} \mathrm{C}$ ) and $t$ is the estimated stage duration. Estimates were also made using the mean carbon mass of succeeding stages.

For Calanoides acutus estimates of $g$ ranged from $0.04 \mathrm{~d}^{-1}$ for stages CIV at the ECB on-shelf to $0.33 \mathrm{~d}^{-1}$ for CII at the WCB off-shelf, and were highly variable among stages and regions. For $C$. acutus the overall average value of $g$ for the range of copepodite stages which were moulting during the experiments was $0.14 \mathrm{~d}^{-1}$. In contrast, $g$ for Rhincalanus gigas was much less variable among regions and was generally lower than for $C$. acutus, with the average value for all moulting stages at all stations being $0.05 \mathrm{~d}^{-1}$. Values ranged from 0.02 for stage CII at the ECB and WCB off-shelf up to 0.08 for stage $C I$ at the WCB off-shelf. In the markedly richer food environment of the WCB off-shelf where growth rates for $C$. acutus were considerably higher they showed some evidence of decreasing with successively older stages.

\section{DISCUSSION}

In this study we have examined the growth response of early copepodite stages for 2 important species of Antarctic copepods to a range of environmental conditions. In order to assess our results we first need to examine aspects of the methodology which may influence interpretation.

\section{Methodology}

We have no way of knowing for sure whether moulting bursts, suggested by Miller et al. (1984) to be a potential problem with this method, were occurring in our experiments, but a comparison of the current methodology with periodic sampling of a tank reared population of Calanus helgolandicus (Shreeve et al. 1998) revealed no significant differences in moulting rates. Likewise Runge et al. (1985) found that experimentally derived moulting rates agree well with in situ changes in age structure. The dry masses of newly moulted individuals of both species generally lay at the upper end of the previous stage and the lower end of the current one (Fig. 3). Thus newly moulted individuals did not represent a random spread of individual dry masses within stage but were restricted to the heaviest individuals of that stage, suggesting, as Miller et al. (1984) proposed for Calanus pacificus, that a threshold is reached beyond which moulting occurs, even in the absence of food.

The method employed is also sensitive to the age within stage distribution of the species studied. Protracted recruitment in these species has been reported by Marin (1988) and Atkinson (1991), which would suggest that age within stage of these species is often normally distributed. However in populations where recruitment has just commenced there may be insufficient individuals within a stage old enough to moult. This is unlikely to have been the case for Calanoides acutus in which recruitment commences as early as October (Andrews 1966) and the stage durations in this study were short. For Rhincalanus gigas however it is possible that such biases were introduced. Ward et al. (1997) indicated that the appearance of CI in the South Georgia region takes place in November at the earliest. Given the stage durations reported here for a period corresponding to some 4 to $6 \mathrm{wk}$ later, it is possible that CIII in particular may have unbalanced age within stage distributions, i.e. insufficient individuals old enough to moult.

\section{Factors affecting growth}

Of the variables that affect growth and development in copepods, sea surface temperature remained at around $3^{\circ} \mathrm{C}$ at all 4 regions during the sampling period, whereas food concentration, expressed in terms of algal carbon, varied considerably among sites. The availability of this carbon is further affected by the size of the micro-plankton, as copepods generally tend to be inefficient at filtering food items less than $5 \mu \mathrm{m}$ (Nival \& Nival 1976, Berggreen et al. 1988). In the WCB on-shelf region the great majority of food items had a largest dimension of $5 \mu \mathrm{m}$ or less, so although the algal carbon biomass was relatively high in this box (9.63 $\left.\mathrm{g} \mathrm{C} \mathrm{m}^{-2}\right)$ most of this may have been unavailable to the copepods. Large diatoms which characterised the microplankton assemblage in the WCB off-shelf provide food items of the optimum particle size for the larger copepods, Rhincalanus gigas and Calanoides acutus (Atkinson 1995). In this region the biomass of copepods was greater and the growth rates of $C$. acutus higher than elsewhere. Although $C$. acutus is capable of feeding on heterotrophic taxa (Atkinson 1995 , Atkinson et al. 1996), it mainly consumes phytoplankton (Atkinson 1998) and its growth rate was correspondingly lower in the ECB, where there was less microplankton carbon $\left(<6.13 \mathrm{~g} \mathrm{C} \mathrm{m}{ }^{-2}\right.$ ) comprised mostly of small cells and ciliates. $R$. gigas growth rates 
were not so severely reduced in the ECB. We speculate that this is because it is a more opportunistic feeder (Graeve et al. 1994) and is able to utilize a wider range of food taxa than C. acutus.

Stage-specific growth rates are a product of the carbon mass of successive stages and the length of time an individual stays in that stage. Species-specific stage durations were however not significantly different among regions, although as we have seen there was a significant difference among stations in the weight of individuals both in terms of the mean weight of newly moulted individuals and the mean weight for all individuals within that stage. This is consistent with the suggestion of Miller \& Tande (1993) for Calanus finmarchicus that moulting rates are much less sensitive to food limitation than is growth and the size attained by the adult. Our data (Fig. 3) also show that there appears to be a minimum mass at which individuals moult to the next stage, which varied among regions, and, as temperature was uniform, was presumably dependent on the feeding history of the copepod. This supports the suggestion of Carlotti \& Sciandra (1989) that there is a critical moulting mass for a given stage which increases as food concentration increases. However, their suggestion that at low food levels a lower specific growth rate leads to slower moulting rates is not supported by our data because in our experiments stage duration was not significantly affected by food concentrations available to the copepodites.

\section{Comparisons with other studies}

Our estimates of $g$ for the range of stages of both species from all 4 regions (Table 4 ) is within the range of literature values for copepods growing at similar temperatures (Huntley \& Boyd 1984, Hirst \& Sheader 1997). We have compared the amount of carbon that would need to be ingested to support these growth rates with published ingestion rates. Ingestion. rates of the younger copepodite stages were derived by scaling those of older stages (Schnack et al. 1985, Atkinson et al. 1996) using an allometric exponent for mass-specific ingestion rates of 0.377 (Ikeda 1977). We have assumed the fraction of ingested food available for growth to be $50 \%$, as calculated for Calanus pacificus from Puget Sound by Vidal (1980). Although Vidal's experiments were conducted at 8 to $15^{\circ} \mathrm{C}$, temperature was shown to have only a slight effect on growth efficiency (Vidal 1980). The range of growth rates estimated from ingestion rates for each stage are shown in Table 4. In all cases our measured growth rates would be supported adequately by the estimated ingestion rates.
Development rates measured in these experiments may be compared with those given in the literature estimated from population stage frequency data. Rapid moulting in the younger stages of Calanoides acutus suggested by the data of Andrews (1966), Atkinson (1991) and Atkinson et al. (1997) is supported by our data. The combined duration of stages CII to CIV at the WCB off-shelf is $23 \mathrm{~d}$. Similarly, although there is often no clear cohort progression in the population of Rhincalanus gigas, Ward et al. (1997) estimated that the development time for $R$. gigas stages CI to CIV was approximately 2 mo. A similar duration was measured at the WCB off-shelf, where summing the stage durations for the same range of copepodite stages indicated that $62 \mathrm{~d}$ would be required. Moulting rates measured in this study are therefore comparable with the fastest estimates derived from stage frequency data. However, our data show that there is considerable variability in dry and carbon mass and growth rates over the relatively small spatial scale sampled. Previous work around South Georgia has shown similar regional heterogeneity in copepod stage frequency and abundance at this time of year (Atkinson 1989), and also in phytoplankton abundance and species composition (Priddle et al. 1986). Consequently it is important that species abundance, biomass and growth are measured accurately at the appropriate scales, rather than averaged values applied, if we are to understand how energy is transferred between trophic levels.

Acknowledgements. We thank the officers and crew of the RRS 'James Clark Ross', our colleagues within the Pelagic Ecosystem programme for assistance in the field, and Dr M. A. Brandon for data on the physical Oceanography. D. G. Bone designed and made the motion compensating net. Comments by Drs A. Atkinson, A. Hirst and the 3 anonymous referees considerably improved the manuscript.

\section{LITERATURE CITED}

Andrews KJH (1966) The distribution and life-history of Calanoides acutus (Giesbrecht). Discovery Rep 34:1-116

Atkinson A (1989) Distribution of six major copepod species around South Georgia in early summer. Polar Biol 9. $353-363$

Atkinson A (1991) Life cycles of Calanoides acutus, Calanus simillimus and Rhincalanus gigas (Copepoda: Calanoida) within the Scotia Sea. Mar Biol 109:79-91

Atkinson A (1995) Omnivory and feeding selectivity in five copepod species during spring in the Bellingshausen Sea, Antarctica. ICES J Mar Sci 52:385-396

Atkinson A (1998) Life cycle strategies of epipelagic copepods in the Southern Ocean. J Mar Syst 15:289-311

Atkinson A, Shreeve RS, Pakhomov EA, Priddle J, Blight SP, Ward P (1996) Zooplankton response to a phytoplankton bloom near South Georgia, Antarctica. Mar Ecol Prog Ser $144: 195-210$

Atkinson A, Schnack-Schiel SB, Ward P (1997) Regional differences in the life cycle of. Calanoides acutus (Copepoda: 
Calanoida) within the Atlantic sector of the Southern Ocean. Mar Ecol Prog Ser 150:99-111

Bathmann UV, Makarov RR, Spiridonov VA, Rohardt G (1993) Winter distribution and overwintering strategies of the Antacrtic copepod species Calanoide acutus, Rhincalanus gigas and Calanus propinquus (Crustacea, Calanoida) in the Weddell Sea. Polar Biol 13:333-346

Berggreen U, Hansen B, Kiorboe $T$ (1988) Food size spectra, ingestion and growth of the copepod Acartia tonsa during development: implications for determination of copepod production. Mar Biol 99:341-352

Carlotti F, Sciandra A (1989) Population dynamics model of Euterpina acutifrons (Copepoda: Harpacticoida) coupling individual growth and larval development. Mar Ecol Prog Ser 56:225-242

Conover RJ, Huntley M (1991) Copepods in ice-covered seadistribution, adaptations to seasonally limited food, metabolism, growth patterns and life cycle strategies in polar seas. J Mar Syst 2:1-41

Everson I (1977) The living resources of the Southern Ocean. FAO, Rome

Graeve M, Hagen W, Kattner G (1994) Herbivorous or omnivorous? On the significance of lipid composition as trophic markers in antarctic copepods. Deep-Sea Res I 41(5/6): 915-924

Hagen W, Schnack-Schiel SB (1996) Seasonal lipid dynamics in dominant Antarctic copepods: energy for overwintering or reproduction? Deep-Sea Res I 43(2):139-158

Hart RC (1990) Copepod post-embryonic durations: pattern. conformity, and predictability. The realities of isochronal and equiproportional development, and trends in the copepodid-nauplii duration ratio. Hydrobiologia 206:175-206

Hart TJ (1942) Phytoplankton periodicity in Antarctic surface waters. Discovery Rep 21:261-356

Hirst AG, Sheader M (1997) Are in situ weight-specific growth rates body-size independent in marine planktonic copepods? A re-analysis of the global synthesis and a new empirical model. Mar Ecol Prog Ser 154:155-165

Hopkins TL (1971) Zooplankton standing crop in the Pacific sector of the Antarctic. In: Llano GW, Wallen IE (eds) Biology of the Antarctic Seas 4. Antarct Res Ser 17:347-362

Huntley M, Boyd C (1984) Food-limited growth of marine zooplankton. Am Nat 124(4):455-478

Huntley ME, Lopez MDG (1992) Temperature-dependent production of marine copepods. A global synthesis. Am Nat 140(2):201-242

Ikeda R (1977) Feeding rates of planktonic copepods from a tropical sea. J Exp Mar Biol Ecol 29:263-277

Lopez MDG, Huntley ME, Lovette JT (1993) Calanoides acutus in the Gerlache Strait, Antarctica. 1. Distribution of late copepodite stages and reproduction during spring. Mar Ecol Prog Ser 100:153-165

Marin V (1988) Independent life cycles: an alternative to the asynchronism hypothesis for antarctic calanoid copepods. In: Boxshall GA, Schminke HK (eds) Biology of copepods. Developments in hydrobiology 47 Klewer Academic Press, Dordrecht

Miller CB, Huntley ME, Brooks ER (1984) Post-collection

Editorial responsibility: Otto Kinne (Editor),

Oldendorf/Luhe, Germany molting rates of planktonic copepods: measurements, application, problems. Limnol Oceanogr 29(2):1274-1289

Miller CB, Tande KS (1993) Stage duration estimation for Calanus populations, a modelling study. Mar Ecol Prog Ser 102:15-34

Neave HR (1981) Elementary statistics tables. George Allen \& Unwin, London

Nival P, Nival S (1976) Particle retention efficiencies of an herbivorous copepod, Acartia clausi (adult and copepodite stages): effects on grazing. Limnol Oceanogr 21:24-39

Pakhamov EA, Verheye HM, Atkinson A, Laubscher RK, Taunton-Clark $J$ (1997) Structure and grazing impact of the mesozooplankton community during late summer 1994 near South Georgia, Antarctica. Polar Biol 18: $180-192$

Peterson WT, Tiselius P, Kiørboe T (1991) Copepod egg production, moulting and growth rates, and secondary production, in the Skagerrak in August 1988. J Plankton Res $13: 131-154$

Priddle J, Heywood RB, Theriot E (1986) Some environmental factors influencing phytoplankton in the Southern Ocean. Polar Biol 5:65-79

Runge JA, McLaren IA, Corkett CJ, Bohrer RN, Koslow JA (1985) Molting rates and cohort development of Calanus finmarchicus and C. glacialis in the sea off southwest Nova Scotia. Mar Biol 86:241-246

Schnack SB, Smetacek V, Bodungen BV, Stegmann P (1985) Utilization of phytoplankton by copepods in Antarctic waters during spring. In: Gray JS, Christiansen ME (eds) Marine biology of polar regions and effects of stress on marine organisms. Wiley, Chichester, p 65-81

Schnack-Schiel SB, Hagen W (1994) Life cycle strategies and seasonal variations in distribution and population structure of four dominant calanoid copepod species in the eastern Weddell Sea, Antarctica. J Plankton Res 16: $1543-1566$

Shreeve RS, Ward P, Murray AWA (1998) Moulting rates of Calanus helgolandicus: an inter-comparison of experimental methods. J Exp Mar Biol Ecol 224:145-154

Vidal J (1980) Physioecology of zooplankton. IV. Effects of phytoplankton concentration, temperature, and body size on the growth rate of Calanus pacificus and Pseudocalanus sp. Mar Biol 56:111-134

Voronina NM (1970) Seasonal cycles of some common antarctic copepod species. In: Holdgate MV (ed) Antarctic ecology. Academic Press, London, p 162-172

Voronina NM, Vladimirskaya YeV, Zmivevskaya MI (1978) Seasonal variation in the age composition and vertical distribution of common zooplankton species in the Southern Ocean. Oceanology Wush 18:335-338

Ward P. Shreeve RS (1995) Egg production in three species of Antarctic calanoid copepods during an austral summer. Deep-Sea Res I 42(5):721-735

Ward P, Atkinson A, Schnack-Schiel SB, Murray AWA (1997) Regional variation in the life cycle of Rhincalanus gigas (Copepoda: Calanoida) in the Atlantic Sector of the Southern Ocean-re-examination of existing data (1928 to 1993). Mar Ecol Prog Ser 157:261-275

Submitted: October 9, 1997, Accepted: August 27, 1998

Proofs received from author(s): November 30, 1998 